\title{
OPTIMALISASI COMPUTER MEMORY USAGE MENGGUNAKAN METODE APLIKASI MICROSOFT BINDER
}

\author{
Putu Gde Sukarata, I Gede Suputra Widharma, I Made Purbhawa, \\ I Gede Wahyu Antara Kurniawan \\ Teknik Elektro, Politeknik Negeri Bali, Bukit Jimbaran, Badung \\ sukarata@pnb.ac.id
}

\begin{abstract}
Now, the development of computer technology very much developed far from previous years. This development occurs in all areas of life. Like the world of medicine, industry, agriculture and others. Technology also greatly helps the various jobs of human beings become easier, faster and efficient. Computer technology is in the form of hardware and software. The software used can be both system and application. To run these systems and applications requires hardware in the form of spaces as a store called memory. Memory has a temporary and permanent nature. The amount of memory space will affect the computer working system and running applications used. More and more applications are used, will automatically be able to meet the existing memory space. The Microsoft Binder application is one of the less-known features of its use as a document binder generated from various applications. Microsoft Binder is like a binding clip and saves related documents simultaneously. Microsoft Binder allows us to merge various files into one for easy management. In this case the use of memory that is used will certainly be reduced so that the computer work becomes more optimal.
\end{abstract}

Keywords: Hardware, Software, Memory, Microsoft Binder, Optimal

\begin{abstract}
Abstrak
Perkembangan teknologi komputer sekarang ini sangat jauh berkembang dari tahun-tahun sebelumnya. Perkembangan ini terjadi di semua bidang kehidupan. Seperti dunia kedokteran, industri, pertanian dan yang lainnya. Teknologi juga sangat membantu berbagai pekerjaan manusia menjadi lebih mudah, cepat dan efisien. Teknologi komputer ini berupa perangkat keras dan perangkat lunak. Perangkat lunak yang digunakan dapat berupa sistem dan aplikasi. Untuk menjalankan sistem dan aplikasi ini memerlukan perangkat keras berupa ruang-ruang sebagai tempat menyimpan yang disebut dengan memory. Memory memiliki sifat sementara dan permanen. Besarnya ruang memory ini akan mempengaruhi sistem kerja komputer dan berjalannya aplikasi yang digunakan. Semakin banyak aplikasi yang digunakan, otomatis akan dapat memenuhi ruang memory yang ada. Aplikasi Microsoft Binder adalah salah satu fitur yang tidak terlalu banyak diketahui penggunaannya sebagai pengikat dokumen yang dihasilkan dari berbagai aplikasi. Microsoft Binder seperti klip pengikat dan menyimpan dokumen terkait secara bersamaan. Microsoft Binder memungkinkan kita menggabungkan berbagai file menjadi satu untuk memudahkan pengelolaan. Dalam hal ini penggunaan memory yang terpakai sudah tentu akan berkurang sehingga kerja komputer menjadi lebih optimal.
\end{abstract}

Kata Kunci: Perangkat Keras, Perangkat Lunak, Memory, Microsoft Binder, Optimal

\section{PENDAHULUAN}

Kemajuan teknologi dewasa ini sangat pesat dan meliputi semua disiplin ilmu. Khususnya dalam teknologi komputer, penggunaan komputer dalam kehidupan sehari-hari sudah tidak dapat dilepaskan dengan gaya hidup. Hampir setiap kegiatan atau pekerjaan yang dilakukan sangat terbantu dengan adanya komputer.

Teknologi komputer terdiri dari perangkat keras dan perangkat lunak. Untuk menjalankan perangkat lunak yang biasanya berupa sistem dan aplikasi memerlukan perangkat keras berupa memory dan perangkat lain. Salah satu faktor yang mempengaruhi kecepatan kerja komputer adalah 
banyaknya ruang memory yang terpasang. Pengelolaan ruang memory sangat penting ketika perangkat lunak yang digunakan sudah tidak mencukupi (Faradina Harumi, 2014).

Pada komputer, jumlah memory yang tersedia adalah jumlah antara memory fisik dengan virtual memory. Virtual memory adalah sebuah porsi pada hard disk yang di-set menyerupai RAM (Random Acces Memory) oleh system. Virtual memory merupakan ruang penyimpanan sementara yang digunakan untuk menjalankan program yang membutuhkan memory yang lebih besar dari memory fisik. Virtual memory berupa file yang bernama pagefile.sys yang di-set hidden oleh Windows. File ini disebut paging file, yang digunakan untuk menampung program dan data yang tidak cukup di memory fisik. Virtual memory lebih lambat daripada memory fisik, dan penggunaan yang terlalu banyak dapat menurunkan kinerja sistem. Sehubungan dengan itu, windows memindahkan proses yang tidak terlalu sering ke virtual memory, dan membiarkan proses yang sering digunakan di memory fisik (Habibullah Al Faruq, 2015).

Microsoft Binder digunakan sebagai pengikat beberapa dokumen secara bersamaan. Dalam hal pengelolaan juga lebih mudah dan gampang disebabkan karena aplikasi Microsoft Binder ini tidak perlu bolak balik membuka dokumen yang terikat dalam binder ini. Dengan mengimplemantasikan Aplikasi Microsoft Binder dapat mengoptimalisasi penggunaan memory pada komputer secara maksimal. Salah satu cara membuat kinerja komputer tersebut menjadi optimal adalah dengan mengelola penggunaan ruang memory yang ada. Untuk mengetahui penggunaan ruang memory komputer yang terpakai saat beberapa aplikasi sedang dijalankan pada waktu yang sama dapat menggunakan beberapa alat ukur.

Microsoft Binder merupakan Aplikasi yang dapat digunakan dengan tujuan :

$\checkmark$ Tujuan Umum : menjadi salah satu aplikasi yang dapat mempercepat kinerja komputer pada saat menjalankan beberapa aplikasi.

$\checkmark \quad$ Tujuan Khusus : menghasilkan jumlah ruang memory lebih banyak terhadap beberapa aplikasi yang sedang berjalan.

$\checkmark$ Tujuan Operasional : mengetahui jumlah memory tersisa dengan alat ukur Task Manager, Sistem Explorer dan Process Explorer

\section{METODE PENELITIAN}

\section{Rancangan Penelitian}

Rancangan penelitian ini digambarkan sebagai berikut:

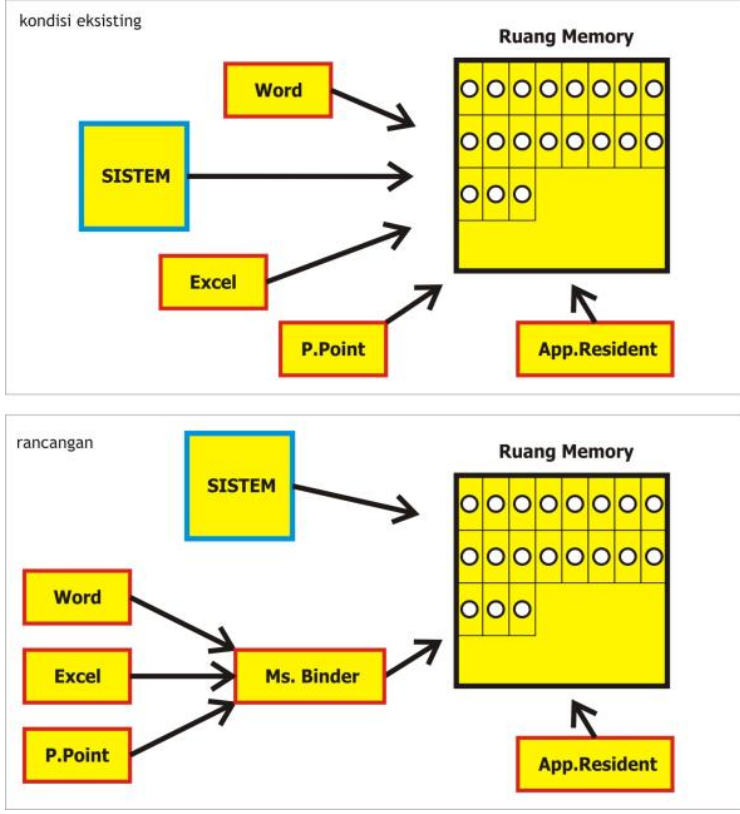

Gambar 1. Blok Diagram Rancangan

Dari gambar di atas merupakan konsep penelitian yang dapat dijelaskan dengan langkahlangkah sebagai berikut:

1. Menyiapkan berkas-berkas yang berkaitan satu sama lain, misalkan berkas microsoft word, microsoft excel dan microsoft powerpoint dan atau yang lainnya.

2. Menggunakan Microsoft Binder membuat file binding untuk mengikat berkas-berkas yang sudah disiapkan.

3. Membuka file binding yang sudah berisi berkas-berkas seperti diatas.

4. Mengolah berkas-berkas yang sudah dibinding tanpa harus membuka aplikasi yang berkaitan dengan berkas-berkas tersebut secara bersamaan.

5. Melakukan pengukuran terhadap penggunaan ruang memory yang terpakai.

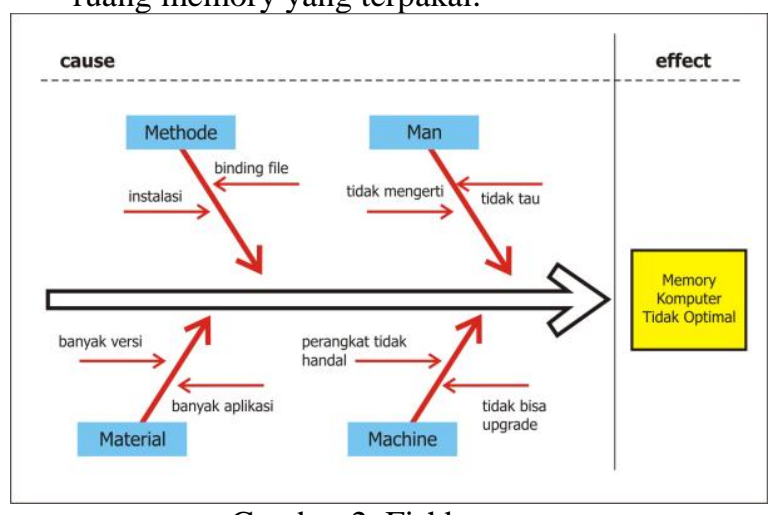

Gambar 2. Fishbone

\section{Diagram Alir}

Penelitian ini dimulai dengan menyiapkan data-data pendukung seperti sistem windows, aplikasi word, excel, powerpoint, photoshop, corel draw, aplikasi anti virus sebagai aplikasi resident memory dan beberapa aplikasi lain. Pengukuran 
memory yang tersisa menggunakan Task Manager, Sistem Explorer dan Process Explorer.

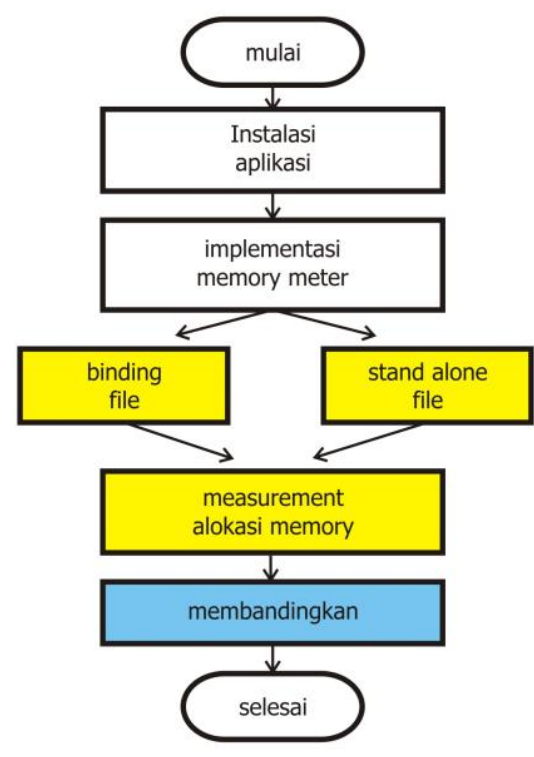

Gambar 3. Diagram Alir Penelitian

\section{Prosedur Penelitian}

1. Instalasi sistem pada komputer dengan versi Sistem Windows XP SP3 serta beberapa aplikasi lain seperti Microsoft Word, Microsoft Excel, Microsoft Powerpoint, Microsoft Binder, aplikasi grafis seperti Adobe Photoshop, Corel Draw, Macromedia Flash.

2. Implementasi Memory meter dengan menggunakan yang sudah secara default ada yaitu Task Manager dan menginstalasi dua alat ukur penggunaan memory yang lain yaitu Process Explorer dan System Explorer.

3. Membinding berkas-berkas dengan Microsoft Binder

4. Pengukuran alokasi memory pada kondisi terbinding dan tidak terbinding.
5. Membandingkan hasil pengukuran ruang memory tersisa antara berkas-berkas terbinding dan tidak terbinding dengan ketiga alat ukur yang digunakan.

\section{HASIL DAN PEMBAHASAN}

Salah satu fitur yang paling tidak diketahui namun paling berguna di Office 95, 97, dan 2000 adalah Microsoft Office Binder, sebuah utilitas yang memungkinkan Kita mengikat dokumen Word, lembar kerja Excel, file Microsoft Project, dan presentasi PowerPoint bersama dalam satu file tanpa harus memuat program terpisah Setiap bagian menjadi bagian dari file pengikat.

Kita dapat menyimpan dokumen, lembar kerja, dan presentasi terkait, melompat bolak-balik dari satu jenis data ke data lain dengan mudah saat Kita melompat dari satu lembar kerja ke lembar kerja lain di buku kerja Excel. Kita juga dapat mengekspor bagian-bagian ini ke file individual sesuai kebutuhan (menggunakan perintah Section Save As File) atau menambahkan file yang sudah ada ke file pengikat (dengan menggunakan perintah Section - Add From File).

Tabel 1

\begin{tabular}{|l|l|l|l|}
\hline \multicolumn{2}{|c|}{ Aplikasi Standart } & \multicolumn{2}{c|}{ Aplikasi Grafis } \\
\hline Ms. Word & Proposal_dipa2018.doc & Photoshop & Rancangan.psd \\
\hline Ms. Excel & RAB_dipa2018.xls & CorelDraw & Fishbone.cdr \\
\hline PowerPoint & Presentasi_dipa2018.ppt & Flash & Animasi_logo.fla \\
\hline
\end{tabular}

Berkas yang digunakan untuk penelitian

Sumber: Data primer yang akan diolah

Alat ukur memory meter yang digunakan adalah Task Manager, Process Explorer, System Explorer 


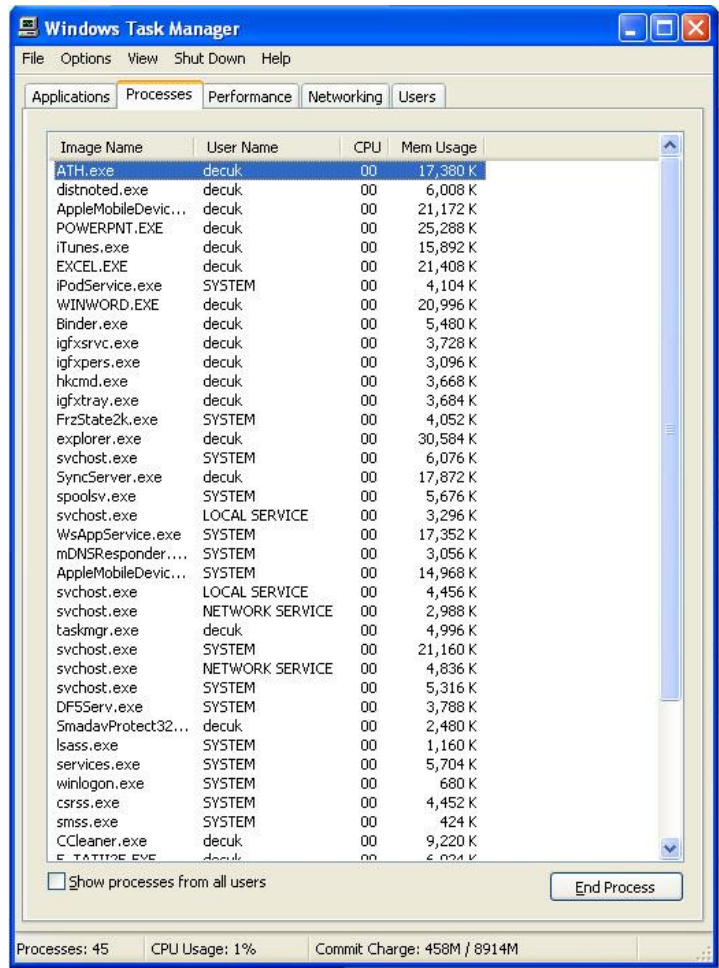

Aplikasi Standart-Binder-Task Manager

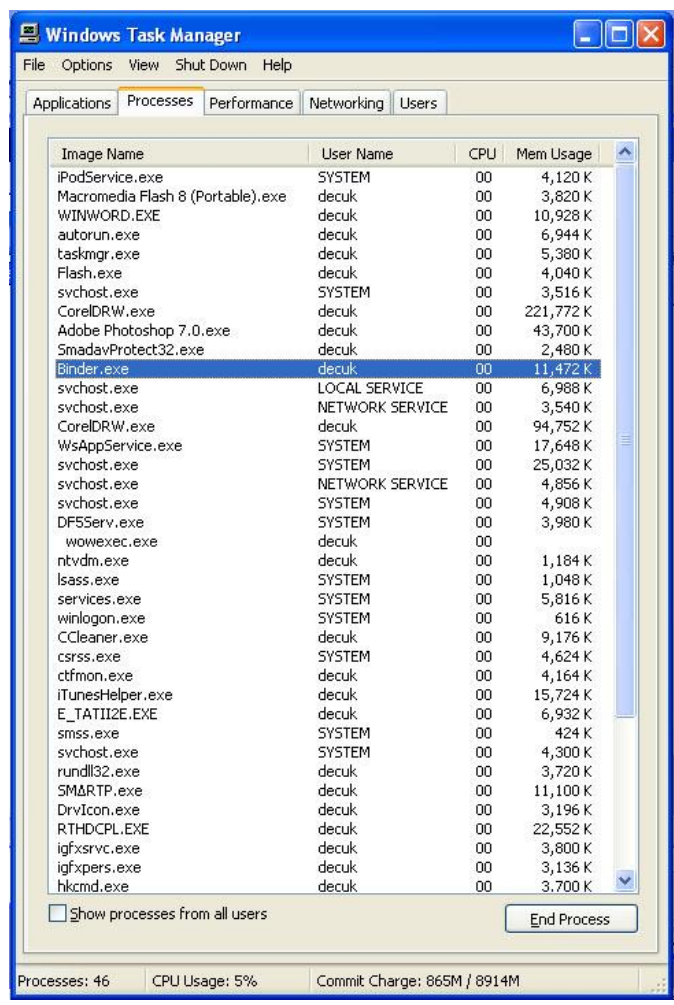

Aplikasi Grafis-Binder-Task Manager

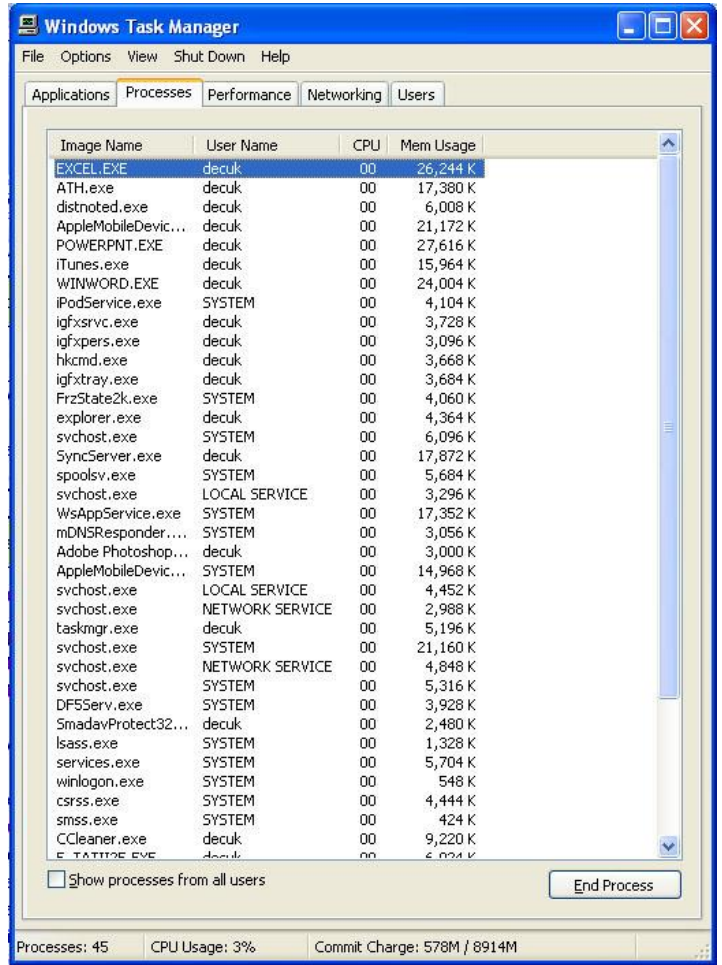

Aplikasi Standart-Stand Alone-Task Manager

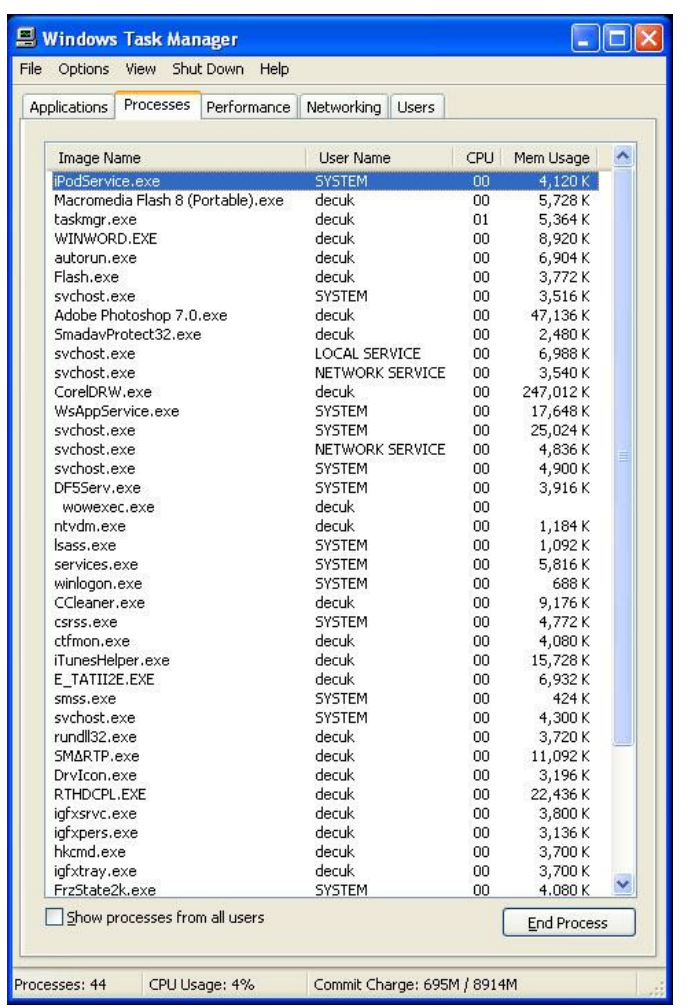

Aplikasi Grafis-Stand Alone-Task Manager 


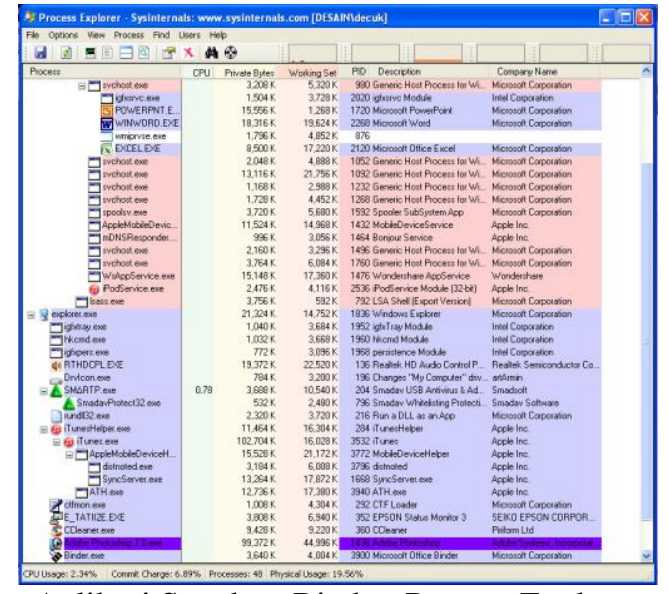

Aplikasi Standart-Binder-Process Explorer

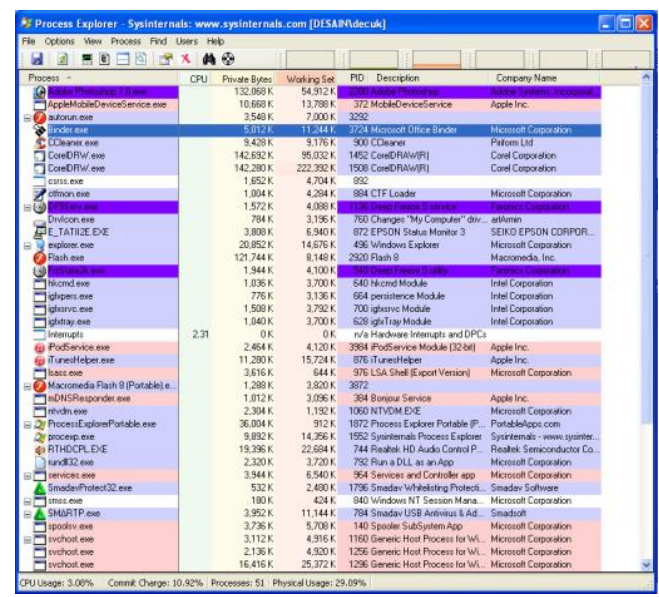

Aplikasi Grafis-Binder-Process Explorer

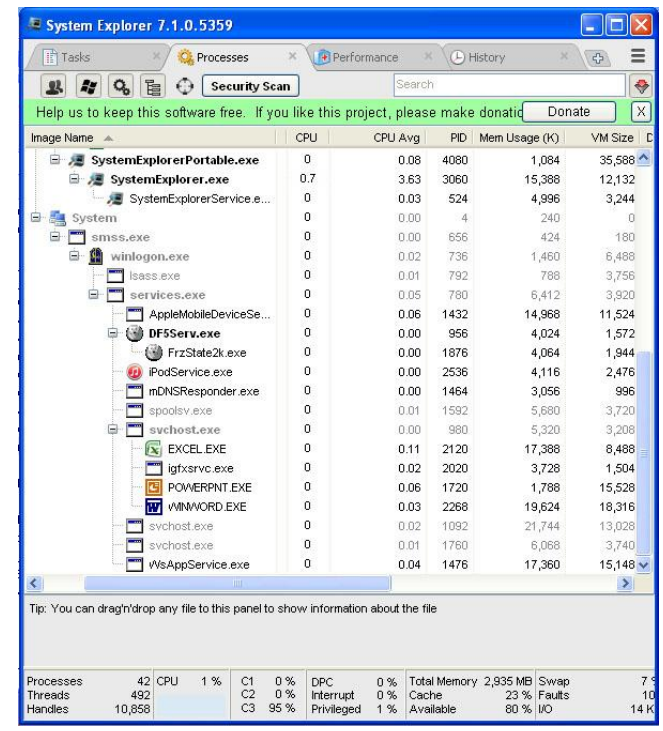

Aplikasi Standart-Binder-System Explorer

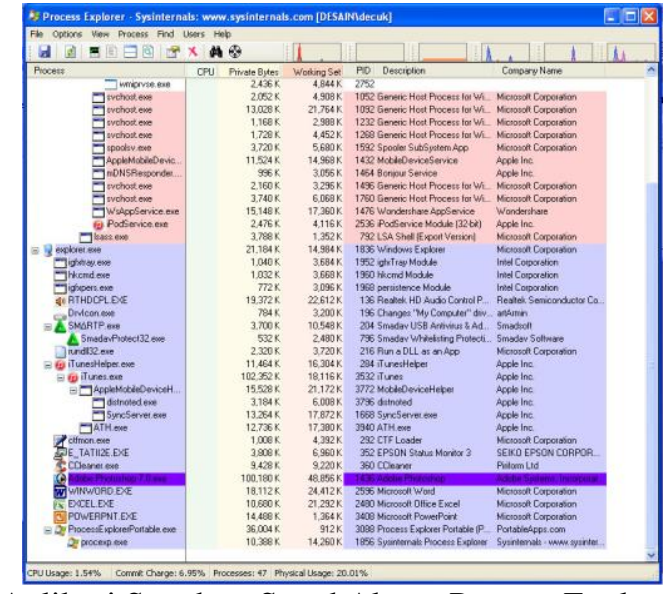

Aplikasi Standart-Stand Alone-Process Explorer

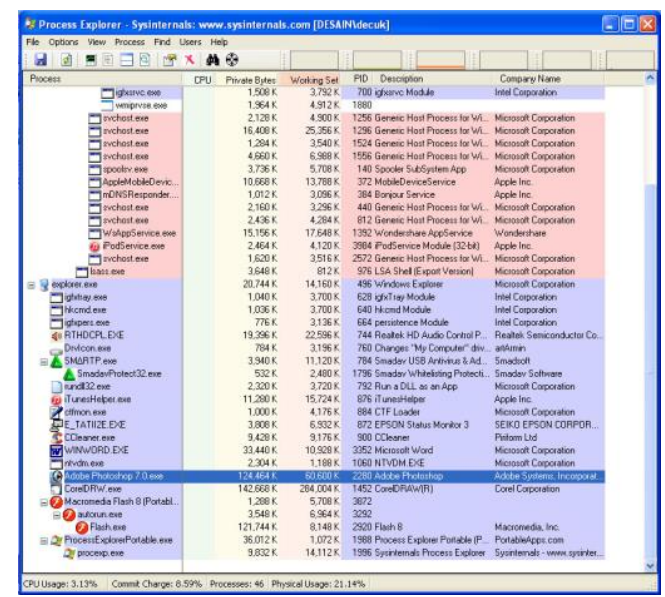

Aplikasi Grafis-Stand Alone-Process Explorer

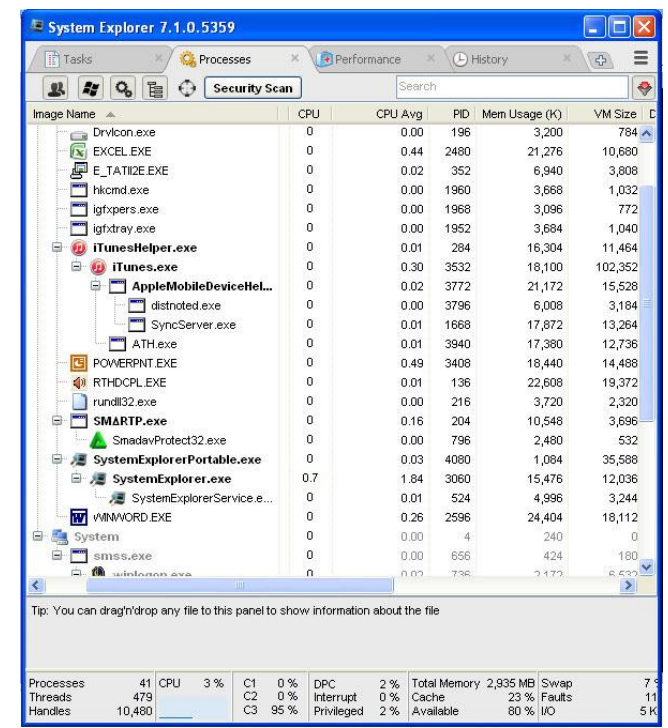

Aplikasi Standart-Stand Alone-System Explorer 


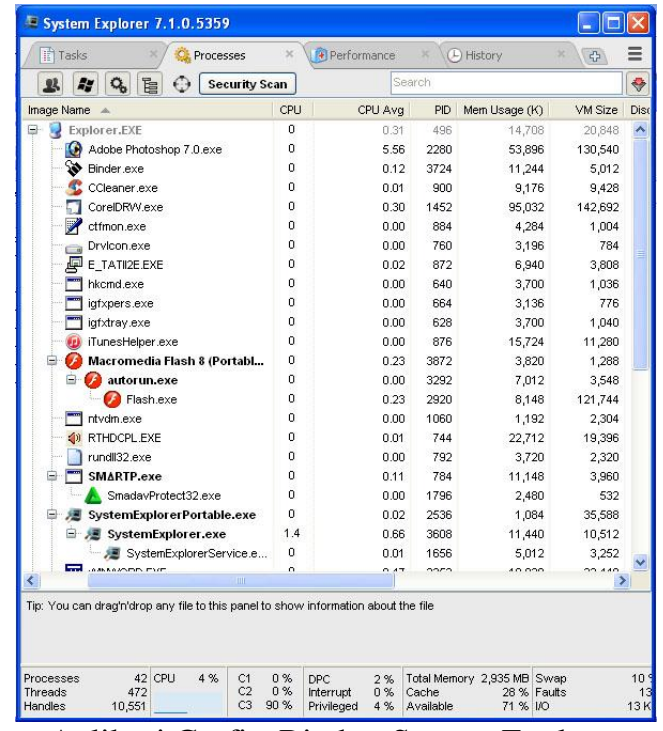

Aplikasi Grafis-Binder-System Explorer

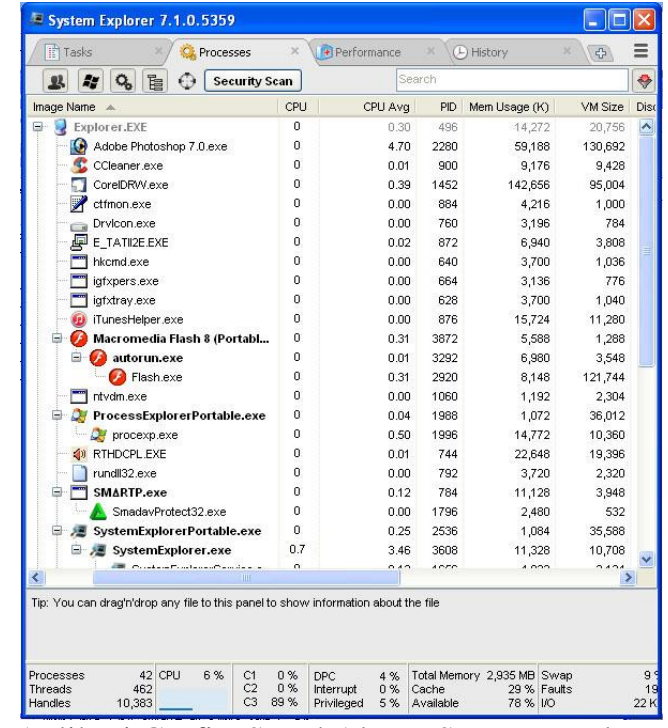

Aplikasi Grafis-Stand Alone-System Explorer

Tabel 2

Hasil Pengukuran dengan Task Manager

\begin{tabular}{|c|c|c|c|c|c|}
\hline Alat & \multicolumn{2}{|c|}{ Aplikasi } & Ms. Binder & Stand Alone & Ruang Sisa \\
\hline \multirow{10}{*}{ 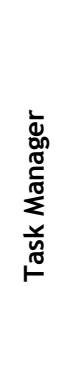 } & \multirow{3}{*}{ Standart } & Ms. Word & 20996 & 24004 & 3008 \\
\hline & & Ms. Excel & 21408 & 26244 & 4836 \\
\hline & & Powerpoint & 25288 & 27616 & 2328 \\
\hline & & Ms. Binder & 5480 & 0 & -5480 \\
\hline & & & 73172 & 77864 & 4692 \\
\hline & \multirow{4}{*}{ Grafis } & Photoshop & 43700 & 47136 & 3436 \\
\hline & & Coreldraw & 221772 & 247012 & 25240 \\
\hline & & Flash & 3820 & 5728 & 1908 \\
\hline & & Ms. Binder & 11472 & 0 & -11472 \\
\hline & & & 280764 & 299876 & 19112 \\
\hline
\end{tabular}

Sumber: Data eksisting setelah menggunakan Ms. Binder

Tabel 3

Hasil Pengukuran dengan Process Explorer

\begin{tabular}{|c|c|c|c|c|c|}
\hline Alat & \multicolumn{2}{|c|}{ Aplikasi } & Ms. Binder & Stand Alone & Ruang Sisa \\
\hline \multirow{10}{*}{ 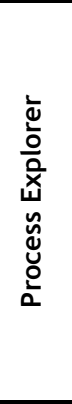 } & \multirow{3}{*}{ Standart } & Ms. Word & 19624 & 24412 & 4788 \\
\hline & & Ms. Excel & 17220 & 21292 & 4072 \\
\hline & & Powerpoint & 12680 & 13640 & 960 \\
\hline & & Ms. Binder & 4004 & 0 & -4004 \\
\hline & & & 53528 & 59344 & 5816 \\
\hline & \multirow{4}{*}{ Grafis } & Photoshop & 54912 & 60600 & 5688 \\
\hline & & Coreldraw & 222392 & 284004 & 61612 \\
\hline & & Flash & 3820 & 5708 & 1888 \\
\hline & & Ms. Binder & 11244 & 0 & -11244 \\
\hline & & & 292368 & 350312 & 57944 \\
\hline
\end{tabular}

Sumber: Data eksisting setelah menggunakan Ms. Binder 
Tabel 4

Hasil Pengukuran dengan System Explorer

\begin{tabular}{|c|c|c|c|c|c|}
\hline Alat & \multicolumn{2}{|c|}{ Aplikasi } & Ms. Binder & Stand Alone & Ruang Sisa \\
\hline \multirow{10}{*}{ 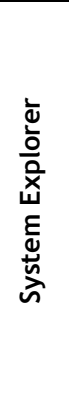 } & \multirow{3}{*}{ Standart } & Ms. Word & 19624 & 24404 & 4780 \\
\hline & & Ms. Excel & 17388 & 21276 & 3888 \\
\hline & & Powerpoint & 17780 & 18440 & 660 \\
\hline & & Ms. Binder & 4355 & 0 & -4355 \\
\hline & & & 59147 & 64120 & 4973 \\
\hline & \multirow{4}{*}{ Grafis } & Photoshop & 53896 & 59188 & 5292 \\
\hline & & Coreldraw & 95032 & 142656 & 47624 \\
\hline & & Flash & 3820 & 5588 & 1768 \\
\hline & & Ms. Binder & 11244 & 0 & -11244 \\
\hline & & & 163992 & 207432 & 43440 \\
\hline
\end{tabular}

Sumber: Data eksisting setelah menggunakan Ms. Binder

\section{SIMPULAN}

Dari penelitian yang sudah kami lakukan dapat disimpulkan bahwa dengan cara mengikat berkasberkas menjadi satu binding maka penggunaan ruang memory yang terpakai dapat tersisa antara lain :

1. Aplikasi Standart diukur dengan Task Manager tersisa 4692K Byte

2. Aplikasi Grafis diukur dengan Task Manager tersisa 19112K Byte

3. Aplikasi Standart diukur dengan Process Explorer tersisa 5816 Byte

4. Aplikasi Grafis diukur dengan Process Explorer tersisa 57944K Byte

5. Aplikasi Standart diukur dengan System Explorer tersisa 4973K Byte

6. Aplikasi Grafis diukur dengan System Explorer tersisa 43440K Byte

Serta jendela-jendela yang ada pada desktop komputer dapat diminimalis begitu pula keterkaitan satu berkas dengan berkas yang lain mudah dilacak.

Microsoft Binder yang digunakan dalam penelitian ini hanya compatible dengan System Windows Model 32 Bit.

\section{DAFTAR PUSTAKA}

1. Faradina Harumi, 2014, Analisis Penggunaan Memory Pada Perangkat Lunak Pemutar Berkas Multimedia, Yogyakarta, Andy Offset.
2. Habibullah Al Faruq, 2015, Pengertian RAM, Fungsi RAM dan Jenis RAM, Yogyakarta, Andy Offset.

3. Krutz, Ronald L. Ph.D, Interfacing Techniques In Digital Design With Emphasis On Microprosessors, Carnegie Mellon University.

4. Rizkiawan, Rizal, Tutorial Perancangan Hardware II, PT. Elexmedia Komputindo, Jakarta

5. Schuler, Charles A and William L.Mc.Namee, Industrial Electronics And Robotics

6. Tirtamiharja, Samuel H Ir.M.Sc, Elektronika Digital, Cetakan Pertama, ANDI, Yogyakarta

\section{Referensi:}

1. Florensius, 2018, Implementasi Alokasi Memory Pada Sistem Komputer Berbasis Clustering K-Means, [online], (http://jptiik.ub.ac.id/index.php/j-

ptiik/article/view/680/282, diakses tanggal 9 Februari 2018)

2. Rauhulloh, 2016, Analisis Memory Usage Pada Game Pro Evolution Soccer, [online], (http://digilib.uin-suka.ac.id/22240/, diakses tanggal 9 Februari 2018)

3. Thomas Tarigan, 2016, Alokasi Memory Citra Bitmap 24 Bit, [online], (https://sriti.akakom.ac.id/prosiding/\%28Thom as\%20Tarigan \%29\%20ANALISIS\%20ALOK ASI\%20MEMORI\%20CITRA\%20BITMAP\% 2024\%20BIT.pdf, diakses tanggal 9 Februari 2018) 